\title{
BUTOR E MICHEL LAUNAY: UM DIALLOGO SOBRE A MORTE
}

\begin{abstract}
Michael Butor, um dog representantes do novo romance francês recebu, em 1957, o prêmio Renaudot pelo seu romance La Modification. Trabalhador incansável, sua obra engloba, hoje, uma série de títulos (Passage de Milan, 1954. L'emploi du temps, 1956. Le génie du lieu, 1958), nos quais se acrescentaram neste ano Vanité e Enroi. Vanité foi baseado no diálogo de Butor com dois amigos. Um deles, Lichel Launay, autor de uma tese que é uma excelente contribuição ao estudo de Rousseau, esteve no Brasil durante três anos como professor da USP. O testemunho foi recolhido por Cecilia Zokner em maio deste ano, em Nice onde ambos residem. $O$ de Michel Butor no dia 4 de maio, na sua casa, Antipodes, às 11 horas da manhã de um domingo chuvoso, logo após o passeio com seu cão. No dia 5, num pequeno restaurante perto da Faculdade, em meio a conversas de estudantes sobre a greve que já durava três meses, Michel Launay falou sobre a sua participaçăo na obra.
\end{abstract}

Michel Butor:

Vanité se origina de uma conversa com dois amigos, um dos quais é Michel Launay e o outro o pintor Henri Maccheroni. Uma conversa que teve lugar na primavera aqui mesmo no terraço e que foi gravada. Foi sobre esse material gravado que eu trabalhei, refazendo-o inteiramente. A publicação foi feita pela Editora Balland porque o editor Jacques Borel é um de meus amigos e naquele momento ele vinha passando por dificuldades e pediu para piblicar um livro meu. Dei-lhe, então, esse pequeno texto. Porém, não estou satisfeito com $a_{1}$ edição. Eu havia feito uma nova versão do texto, acrescentando um certo número de elementos do cenário, procurando transmitir sutilmente o cair da noite sobre Nice. Eles, no entanto, se enganaram e imprimiram a primeira versão em lu. gar da edição definitiva. Evidentemente, isto me desgostou muito a dentro de um certo tempo publicarei o texto definitivo numa coletânea, porém, em outro editor. Ou seja, no momento, não é exatamente como eu gostaria. Na verdade, é muito difícil ser escritor e conseguir que os livros sejam publicados como se quer. Os editores têm uma tendência terrível para mudar as coisas, suprimir. Então, é preciso estar muito atento.

Vanité, como eu dizia, é um diálogo entre três amigos. Pạra separar um pouco o texto da conversa real que aconteceu, para 
mostrar bem que foi transformada, dei aos interlocutores nomes latinos: Pictor, Scriptor e Viator. Não há problema para reconhecer no Pictor o pintor. Escriptor que em latim quer também dizer c secretário (e isto é um pouco de brincadeira) é o escritor Miche! Launay. Viator sou eu, porque se Michel Launay, como também Henri Maccheroni, viajam muito, provavelmente, quem viajou e quem, ainda, viaja mais, sou eu. Além disso, estes nomes latinos evocam um livro de Claudel, de que eu gosto muito, e que se chama Conversation dans le Loir et Cher, um conjunto de quatro diálogos nos quais Claudel deu aos interlocutores nomes latinos. Para mim é um dos mais lindos livros de Claudel e é por isso, aliás, que dei como subtítulo a Vanité, Conversation dans les Alpes Maritimes. E, de certa maneira, uma homenagem ao livro de Claudel.

Michel Launay:

Na primeira página do livro, Michel Butor diz que ele foi feito com Henri Maccheroni, o pintor, e Michel Launay, o professor universitário. Fui convidado, então, por ele e pelo pintor para participar de um diálogo sobre a morte, cujo objetivo seria a publicaçāo de um livro que tinha sido encomendado por determinado editor. Michel Butor transcreveu a gravação de nossa conversa e como ele mesmo diz, a desfez, transformou e depois tornou a tecêla elaborando um novo texto de ritmo muito mais rápido, muito mais allegro que o original. A morte era o tema do livro e propus começar a discussão sobre a palavra com todas as sonoridades que ela cicza para nós. Minhas palavras se originaram do sentimento pela mioi a de minha mãe, em 1967; é a elaboração do luto que continua a se produzir em mim, dez anos depois. A discussão do tema com Butor e Maccheroni que são, também, por diferentes razōes, muito sensíveis a ese tema, ajudou-me a superar a dor que. sinto pela ferda de minha mãe. Para mim, o jogo com as pala. vras começara antes, ao escrever um prefácio para um conjunto de novelas quando se alinhavam as palavras "mãe", "amargo", "morte". (mère, amère, mort). E Butor, ao refeltir sobre a escritura, sobre o trabalho do escritor disse, em muitas páginas de Répertoire, que, por definição, o escritor é alguém que está construindo o seu próprio túmulo. Porque, ao escrever, o escritor se afasta da vida, sem, no entanto, deixar de entreter com ela uma ligação, pois escreve o que vive, mas, vivendo pelo ato de escrever, sofre um corte em relação com a vida que o separa do resto dos vivos. Por outro lado, ao escrever, ele já está começando a morrer, na medida em que se separa da vida, mas, ao mesmo tempo, prepara o seu túmulo para 
cintinuar a nele viver com a ajuda do leitor que, ao abrir o seu livro, o desenterra e faz com que reviva. Existe em Butor uma meditação sobre a relação entre a escritura e o suicídio que vai bastante longe e que aparece no texto Vanité como um dos elementos, entre outros, de diálogo. Mas ele discorre sobretudo subre o elemento principal: a natureza morta, Vaidade, que significa na tradição pictural européia, a partir do século XVI, natureza morta. Nessa época, o quadro que representasse objetos, não era chamacio de natureza morta, mas, partindo de uma meditação sobre a morte praticada pelos monges, Vaidade. Nele havia, então, uma caveira, os símbolos da morte confrontados com as vaidades e os prazeres deste mundo. O título Vanité é, claramente, uma referência à pintura de todo o Ocidente que desde a Idade Média, a partir do crânio, do esqueleto e da evocação dos pecados e dos frazeres medita sobre o tema que continua a perseguir os pintores contemporâneos: há sempre um crânio a passear em cada quadro. Um outro elemento que posso acrescentar para explicar a minha participação positiva no diálogo e que foi recuperada por Butor no seu texto é justamente ligada ao Brasil. Quando lá estive entre 1972 e 1975, conheci os irmãos Vilas Boas, que me mostraram um filme rodado na reserva do Xingu. Fiquei profundamente chocado pela relação dos índios com 0 animal que eles estavam caçando e matando, pela inocência com a qual eles matavam. Ou seja, o ato de matar o animal ou o homem, neles não está ligado a uma idéia de pecado. É um ato de alegria ligado ao ciclo da vida, do reinício da vida. As minhas idéias européias viam pecado e vergonha nas coisas naturais. E culpa em relação à morte, ao ato de matar, ainda que legitimamente. Entre os índios, a inocência das zenas de caça, do tratamento do animal morto, era bem clara. Lembrei esse episódio porque em Vanité na tentativa de lutar contra os tabus ocidentais relacionados com a morte, Butor faz questão de abordar justamente esses assuntos que são evitados. 